Revista Iberoamericana, Vol. LXXVI, Núm. 232-233, Julio-Diciembre 2010, 913-937

\title{
LA SINGULARIDAD DEL DIARIO DE SOLEDAD ACOSTA
}

\author{
POR \\ Daniel Mesa Gancedo \\ Universidad de Zaragoza
}

Durante algo menos de dos años (entre septiembre de 1853 y mayo de 1855), la colombiana SoledadAcosta (Bogotá, 1833-1913) llevó un diario íntimo que, en su original manuscrito, abarca más de 700 páginas. A pesar de lo reciente de su publicación, esta intensa actividad de escritura en los orígenes de la carrera de quien habría de convertirse en una de las más prolíficas escritoras de su tiempo (Rodríguez-Arenas), ha sido ya abordada desde muy diversas perspectivas: la construcción del sujeto, las relaciones con su propia obra y, por supuesto, la autobiografía femenina. ${ }^{1}$ Del cotejo de esos estudios y, sobre todo, de la lectura del propio diario se desprende inequívocamente su carácter singular. Lo es por tratarse de uno de los más antiguos diarios íntimos hispanoamericanos de los que tenemos noticia, pero también por tratarse de un riquísimo diario de lecturas y de una muy consciente reflexión sobre la condición femenina. Es también, a partir de un momento dado, un diario de guerra, testimonio fundamental de un periodo convulso en la historia de la consolidación de la nación.

\section{EL “DIARIO DE GUERRA”}

Este aspecto, quizá, el "menos íntimo" de su diario es el que puede abrir la puerta hacia cuestiones de otro calado. Conviene, pues, preguntarse, por ejemplo, si es posible intentar una lectura histórica de este diario de una joven que está a punto de definir su destino, como mujer y como escritora. Me refiero a una lectura que tenga en cuenta la irrupción de la Historia de la nación en la historia privada de esta muchacha que busca su lugar en el mundo. Semejante lectura puede resultar de lo más pertinente, pues el diario de esta joven colombiana proporciona información de primera mano acerca de uno de los sucesos capitales en la historia de Colombia: la revolución de 1854.

1 Véase Aristizábal Peraza, Ramírez o Vallejo. La editora del texto ha señalado en él "tres hilos conductores": "el de la autobiografía, el de la historia nacional y bogotana de esos años y el de la vida cotidiana” (Alzate, en la introducción a Acosta 2004, XXI). A partir de ahora, todas las citas se harán por la edición consignada en la bibliografía. 
Cuando Soledad Acosta comienza a escribir su diario el 14 de septiembre de 1853, no podía, sin embargo, prever la irrupción de la Historia en su historia, la aparición de la guerra, la proyección del conflicto político sobre sus más íntimos dilemas. Podría decirse que ese diario es el recuento de cómo la vida de la joven pasa de la placidez a la zozobra para, finalmente, recuperar su equilibrio. Su vida real -no escrita- se convierte, a partir de 1852 en una sucesión de alteraciones: la muerte del padre (anterior a la escritura y sólo evocada luego como el suceso que, al hacer conocer el dolor, ha transformado al sujeto $^{2}$ ); la aparición del amante, el político y escritor, José María Samper (en agosto de 1853, aunque se conocen de antes); los celos retrospectivos de Elvira, la primera esposa de su prometido (muerta en 1852); la duda constante de no ser el "anteotipo” de su amado, ${ }^{3}$

2 "18 de noviembre [1853] [...] yo también he tenido una pesadumbre grande: jel perder a su padre! Nadie sabe, nadie ha sondeado hasta el fondo de mi alma y ha visto allí el pesar más grande. Perder, ver desaparecer de la tierra a la única persona que me comprendía, a la única persona que sabía lo que era yo porque me parecía en sus sentimientos, en el genio. Desde el día, desde la noche en que pude persuadirme de la realidad de tanta desgracia, desde ese momento me sentí cambiada, iy cuán cambiada! El pesar había hecho que de una muchacha sin pensamiento, sin ideas, apoyada en mi padre, de repente sintiera que el apoyo se me había ido y que estaba sola. [...] Aquella noche tan amarga, tan terrible,... esa noche me volví independiente de todo y sentí que era otra. Fue grande la pena, tanto más inmensa, tanto, que nunca hablo de mi padre. Me parece un sacrilegio, me parece falta grande hablar de él y aun pensar en él con la sonrisa en los labios. Cuando quiero estar triste pienso en tan grande desgracia. Pero nunca es que siquiera pronuncio esas palabras que me conmueven, y no quiero mostrar mi pena porque mostrarla sería desear que me la alivien, y yo no quiero ser consolada. [...]” (82-83). Indico entre corchetes el año, puesto que no suele aparecer normalmente en la fecha de las entradas, una vez apuntado en la primera del respectivo enero.

3 Con ese término, Soledad se refiere insistentemente a la idea de los amantes "complementarios": "10 de noviembre [1853] "Platón creía en la existencia de un anteotipo espiritual del alma, así es que desde que nacemos tenemos en nuestro interior una cosa que nos impele a buscar y a desear encontrar nuestra semejanza”. [...]" (63). Al ir entre comillas, parece evidente que se trata de una cita, que Acosta no identifica. Creo que se trata de una ajustada paráfrasis de un pasaje del breve ensayo "On Love" de Shelley: "We are born into the world, and there is something within us which, from the instant that we live, more and more thirsts after its likeness". Unas líneas más allá Shelley utiliza el término "antitype”, en un contexto que condice totalmente con el sentido que le da Acosta: "The discovery of its antitype; the meeting with an understanding capable of clearly estimating our own; an imagination which should enter into and seize upon the subtle and delicate peculiarities which we have delighted to cherish and unfold in secret; with a frame whose nerves, like the chords of two exquisite lyres, strung to the accompaniment of one delightful voice, vibrate with the vibrations of our own; and of a combination of all these in such proportion as the type within demands; this is the invisible and unattainable point to which Love tends; and to attain which, it urges forth the powers of man to arrest the faintest shadow of that, without the possession of which there is no rest nor respite to the heart over which it rules”. La crítica suele señalar el origen platónico de esta idea y relaciona la redacción del ensayo con la traducción que Shelley hizo del Banquete en 1818 (Singer, Ulmer). “On Love” se publicó por primera vez en 1829 y fue recogido por Mary W. Shelley en 1840 en la recopilación Essays, letters from abroad, translations and fragments (London, Edward Moxon), reeditada en 1852. Tal vez alguna de estas ediciones pudo llegar a Soledad Acosta, aunque nunca menciona de forma explícita a este autor inglés en su diario. El platonismo del concepto deriva de una reformulación de la teoría del andrógino (Platón 26-29). A continuación de la

Revista Iberoamericana, Vol. LXXVI, Núms. 232-233 Julio-Diciembre 2010, 913-937
ISSN 2154-4794 (Electrónico) 
de que predomine en él la intensidad del “primer amor", irrepetible"; la desaparición del amante tras el golpe de estado de José María Melo (abril de 1854); la guerra; y, por fin, ante la falta de noticias y los rumores sobre su actuación, las sospechas de la cobardía de su amante. Todo se resolverá, finalmente: el amante, íntegro y valeroso, regresará verdaderamente volcado hacia su prometida, comprensivo y preocupado por su formación, y, tras la guerra, será el símbolo de la reordenación del mundo.

El contexto histórico colombiano en el que se desarrolla la obra de Acosta ha sido convenientemente perfilado (Vidales): es un espacio relativamente convulso, como consecuencia del proceso de consolidación del estado republicano independiente. Por las fechas en que Soledad Acosta redacta su diario, tiene lugar una de las revoluciones más importantes que padeció el país en el xıx: la rebelión de José María Melo en 1854. El diario de Acosta, probablemente, es una de las fuentes primarias más interesantes a la hora de interpretar ese suceso, aunque su perspectiva es, necesariamente, parcial.

Las reflexiones de carácter político aparecen desde las primeras páginas del diario y siempre giran en torno al tema del patriotismo. Soledad se siente profundamente “colombiana” y lamenta el estado de las instituciones republicanas, lo que implica, en cierto modo, una crítica del estado patriarcal como punto de partida de la visión política de Acosta:

20 de octubre [1853]. [...] Es horrible, no he visto pueblo más cobarde, viles nociones tienen todos sobre el valor, no conocen la vergüenza y siempre confiesan su falta de valor con la más grande sangre fría. Son las nueve de la noche. Están hablando sobre elecciones que me tienen aburrida. Todo el mundo es de mala fe. ¿Cuándo encontraré un ser, una conciencia pura? Pero en política, ¿̇adónde está la buena fe? Se fue, dejó este mundo, huyó apresurada. [...] ¡Intrigas!, ¡hacer trampas!, ¡engañar, esto es lo que

paráfrasis de Shelley, la autora transcribe un poema de Juan Bautista Arriaza que desarrolla una idea semejante: "No me enamoró tu trato / ni tu semblante perfecto, / sino un simpático afecto / que tal vez nací con él. / Yo me figuré un retrato / de las gracias verdaderas, / y conocí que tu eres / el original de aquel” (63). No me parece inoportuno señalar que la forma "anteotipo" es absolutamente singular en el tesoro léxico español. La forma "antitipo" (más cercana al "antitype” de Shelley y al antitypos griego) existe en el léxico especializado de la hermenéutica bíblica (un contexto poco pertinente en este caso) para referirse a los personajes, episodios o temas del Nuevo Testamento que encuentran su anuncio modelo (typos o "figura”, que es la traducción más frecuente) en el Antiguo Testamento (Cristo respecto de Adán, por ejemplo). Cfr. sólo Frye (103-165).

4 Lo que la moverá a pedirle a él un matrimonio religioso -a pesar de que Samper no es católico en ese momento-, para ser más suya y que él sea más de ella (542) que en el primer matrimonio de Samper, sólo civil. La actitud de la joven ante la religión queda más o menos clara en la entrada del diario de 24 de febrero de 1855: “[...] Yo no soy fanática pero soy profundamente religiosa y creo que la que yo he escogido es la mejor para adorar a Dios. Yo no soy Católica sin haber reflexionado mucho sobre esto... [...] estoy hondamente convencida que [sic] el [culto católico] es el mejor para mí, porque yo creo que la religión de cada uno se encuentra en el fondo de su corazón y en lo que puede creer. [...]” (503).

Revista Iberoamericana, Vol. LXXVI, Núms. 232-233 Julio-Diciembre 2010, 913-937 ISSN 0034-9631 (Impreso) 
llaman ser astutos, tener talento! Estas cosas las cuentan como gracia y llaman servir a la patria; ipobre país, donde los engaños son borrados, y los intrigantes ensalzados! Cuando ven trampas en un partido opuesto dicen que es un horror, que no se debían permitir tales cosas, todo porque no pueden ganar, porque encuentran que son más astutos que ellos; pero cuando suceden las mismas cosas, o tal vez peores, en el partido a que pertenecen, entonces se callan, ipero siempre ayudan en todo lo posible y lo llaman gracia y talento entre ellos! ¡Y de esto se compone el mundo! ¡Esta vida me ha aburrido! ¡Qué haré para no oír tantas cosas que me chocan, que me desagradan! [...]. (38-39)

Soledad desconfía de la política y, reconociéndose “patriota” desde su “más tierna niñez” en el extranjero, le gustaría intervenir para modificar el estado de cosas, pero reconoce que su condición de mujer limita esta posibilidad. ${ }^{5}$ El restringido espacio que está disponible para la acción femenina comenzará a ampliarse en Hispanoamérica justamente a partir de la generación de Soledad Acosta, que en Colombia contaba con escasos precedentes, mencionados en su diario, como Policarpa Salavarrieta o Josefa de Acevedo.

Conforme pasa el tiempo, la política va cobrando en el diario de Acosta una presencia más concreta: la lucha partidista se traslada a sus páginas porque, gracias a José María Samper (que entonces era secretario de la cámara de diputados), Soledad va a conocerla de cerca, en un momento especialmente convulso, que conducirá a la revolución. Soledad apunta juicios concretos sobre el valor intelectual de algunos de los protagonistas del escenario político:

28 de febrero [1854]. Anoche estuvimos en el Congreso. Él nos había mandado a decir que fuéramos, había una interesante discusión. [...] La discusión era sobre el ejército. Éste [Olano] por supuesto estaba a favor de él. Después tomó la palabra el General Herrera pero no pude oír lo que decía. Don Pacho Barriga también habló, ¿pero este pobre hombre qué puede decir digno de oírse? [...]. (141)

La particular "guerra de amor” que la figura de Samper había desencadenado en el interior de la joven (cuyas batallas se sustancian en preguntas como ¿me querrá o no?; ¿mereceré ser querida?; ¿dónde estará mi bien?; ¿debo mostrar mi amor?; ¿se acordará de mí o más de su fantasma?) avanza a partir de este momento en paralelo al

5 “14 de noviembre [1853]. [...] ¡Pero adónde está la fama de Patriota! ¡Ay de mí, que la patria ya no reconoce héroes! ¡Servir a su Patria!... Qué entusiasmo se apodera de mi corazón al oír estas palabras. ¿Pero yo qué puedo hacer! ¡Mujer! Sí, ¡podría hacer algo! ¡Pero adónde está el genio, el talento que se necesita para tan santa misión! [...]” (77). "11 de noviembre [1853]. i[...] siempre, desde mi más tierna niñez, todos mis gustos estaban concentrados en mi patria! ¡Patriotismo! Noble sentimiento que siempre abriga mi alma. Entonces no estaba mezclado con sentimiento alguno. [...] Sueños, la venturanza, todas mis esperanzas entonces se paraban en volverte a ver, ¡oh, tú, Nueva Granada! [...]” (68).

$\begin{array}{llrrr}\text { ISSN 0034-9631 (Impreso) } & \text { Revista Iberoamericana, Vol. LXXVI, Núms. 232-233 Julio-Diciembre 2010, } & 913-937 \\ \text { ISSN 2154-4794 (Electrónico) }\end{array}$ 
conflicto político que lleva a la guerra revolucionaria, una enrevesada querella política que consiguió unir a conservadores y radicales, en defensa de la constitución liberal, contra los reclamos democratizadores de los artesanos, apoyados por el ejército.

Desde luego, la crónica que de esos acontecimientos escribe Soledad Acosta no es neutral: toma partido por la facción que representa su amado, a quien llama “su bien” (y que defiende sus bienes, sus privilegios de clase). Los otros resultan inequívocamente perversos. El malo, para ella, es José María Melo, especie de caudillo populista que encabeza el intento (finalmente fracasado) de desbancar a la burguesía conservadora del poder.

El conflicto se va agudizando desde el mes de marzo y amenaza con afectar directamente a sus intereses particulares:

[6 de marzo 1854]. Estoy siempre llena de susto, cuando pienso en él continuamente estoy creyendo que le puede suceder alguna cosa... Hoy me dijeron que Lleras había reunido a los democráticos para celebrar el 7 de marzo que es mañana. Melo está furibundo porque en el Congreso han querido quitar a los militares. Temen que se amotinen los Soldados con los Democráticos contra los miembros de las Cámaras y maten a los principales Conservadores y radicales o Gólgotas. Muchos no quieren dormir en sus casas de miedo. Murillo entre otros. Y él vive en casa de éste y no quiere esconderse. ¡Estoy sin cesar sobresaltada porque no es improbable que le puedan hacer algún daño! [...] (144)

La guerra sacude al país, o al menos la capital y sus alrededores, entre abril y diciembre de 1854, justo cuando Soledad ya había decidido ser sincera consigo misma y con su amado. O quizá, más bien, parece haber decidido esa sinceridad a causa de la guerra y de la ausencia. Como, además, Soledad quiere ser elocuente, participar de algún modo en el proceso civil que su amante protagoniza, escribe bastante sobre las circunstancias de esa revolución que han llevado a la clandestinidad a "su bien”. Los primeros días de la revuelta, Soledad no puede escribir y cuando por fin lo hace es para lamentarse por el destino de su patria, ${ }^{6}$ pero también, porque sus sentimientos “cívicos” se han contaminado con los "íntimos”:

28 de abril [1854]. [...] ¡Dios mío!, qué es esto, ¡mi alma no siente las desgracias de mi patria, mi corazón no se conmueve y se agita al oír tantas maldades porque sólo una imagen lo llena todo! [...]. (214)

6 “20 de abril [1854]. Por fin mi fiel diario, te vuelvo a hallar. ¡Oh!, ¡cuántas desgracias, cuántas penas he sufrido en estos pocos días! ¡Guerras, alarmas, tristezas y terror! ¡Aun me he visto por tantos días encerrada en el fondo de un monasterio! Dios mío, ¿esto es vivir? ¡Dios mío, por qué abandonas mi desgraciada patria en las manos de los militares salvajes! [...]” (204).

Revista Iberoamericana, Vol. LXXVI, Núms. 232-233 Julio-Diciembre 2010, 913-937 ISSN 0034-9631 (Impreso) 
Durante el conflicto, Soledad pretende "hacer crónica”, dejar constancia de una memoria externa al suceso. Se avergüenza otra vez patrióticamente del estado de su país y unas semanas después del golpe, hace un primer balance:

11 de mayo [1854] [...] Sigue la guerra, o más bien los vándalos que se han apoderado de la ciudad cada día muestran más su tiranía. Han puesto presas a las principales personas de la ciudad... Siguen los atentados de toda especie... Siguen las desgracias de mi pobre patria. Con dolor amargo veo que hasta quién sabe cuándo saldremos de este estado tan vergonzoso, tan indigno... ¡Y llamamos a éste el país de la libertad! ¡Cuando cualquier hombre indigno, despreciable, al tener la fuerza, la tropa armada en su poder, puede cometer todos los robos e infamias que quiere!... Ver los hombres honrados proscritos, los ricos, porque tienen plata, encarcelados, familias llenas de angustia esperando a cada instante que caigan sus padres, maridos, hijos, bajo la cuchilla del asesino. Veo casas rodeadas por los que llaman policía, que es ahora el sinónimo de ladrones, saqueadas por estos hombres bajo el pretexto de buscar algún ser inofensivo y llevarlo a los cuarteles para insultarlo. Veo todo esto con horror y pienso que así es como mi amada patria está insultada, y oigo las risas y alegres sonidos de la guitarra en el cuartel de enfrente. Llena de pesar quisiera esconderme a donde no viera y oyera tantos horrores... [...]. (241-242)

Siente que para una mujer resulta difícil intervenir en el proceso, pero no quiere dejar de intentarlo. Aunque antes se sorprendió de que su patriotismo se hubiera visto menoscabado por su preocupación amorosa, también descubre que a veces la Historia la saca -temporalmente- de su historia, y le ofrece la posibilidad de probar su elocuencia:

9 de junio [1854]. Algunas veces me exalto, olvido por un momento mis pesadas penas y me entusiasmo. Converso con energía y dejo aquella apática melancolía que me oprime el corazón. Pero qué poco dura este estado. [...] Esta tarde estuvimos en casa de las Orrantia. Allí se habló de que esta revolución jamás se acabaría y yo por chanza dije que me pondría a la cabeza de las mujeres y acabaría con todos los enemigos. Volví a casa y a instancias de mi mamá, y curiosa de ver si yo también podría escribir una proclama, la hice. Pero antes de acabar de escribirla se me acabó el entusiasmo y la transitoria excitación pasó, ¡y volví a quedar tan melancólica y sin esperanza como antes! [...]. (284)

Pero, finalmente, es muy difícil separar lo íntimo de lo público en unas circunstancias convulsas como las que la joven está atravesando. Una nota en la que consigna la extensión de la guerra, le lleva a interpretarla casi como "signo de los tiempos” y a ella como víctima de esas circunstancias "universales":

17 de junio [1854]. Hoy hace dos meses que empezó mi desgracia, hace dos meses que empezó esta infame revolución y con ella la triste separación del bien que yo amo.

Revista Iberoamericana, Vol. LXXVI, Núms. 232-233 Julio-Diciembre 2010, 913-937
ISSN 2154-4794 (Electrónico) 
[...] Este año es de Revoluciones en todo el mundo. En Rusia. A Turquía parece que los franceses e ingleses han mandado más tropas. En España, Revolución. Ahora, en la América, Venezuela, Ecuador, el Perú, ¡adonde quiera guerra, guerra! (293)

Consigna noticias, aunque por lo general no está segura de que las que maneja sean ciertas y a menudo tiene que desmentirse (como se ve en notas redactadas con posterioridad). Aunque su visión no es neutral, porque está “comprometida” con la causa constitucionalista -que defiende su familia y su prometido-, procura exponer su propio criterio y juzga equivocadas algunas medidas (como la expulsión del embajador de los EE.UU.) para los intereses de la patria, ${ }^{7}$ del mismo modo que consigna con cierta ironía la confusión ideológica de los rebeldes. ${ }^{8}$

Aunque se le había mezclado el amor a la patria con el amor a Samper, la guerra de amor tiene uno de sus mayores pesares en la conducta aparentemente confusa de su amado durante los primeros meses de la guerra:

8 de agosto [1854] Le escribí a [mi prima] Soledad y le ruego que le hable a *** si acaso va a Guaduas, que le diga, que le haga conocer cuáles son mis sentimientos acerca de su extraña conducta en esta revolución, que le diga lo que pienso. En fin, que le haga entender que para mí no hay nada de noble en su falta de Patriotismo, que yo no puedo amar, admirar a los que en estos tiempos no ayuden en algo a los que tratan de restablecer la Constitución. Dice que porque me ama se maneja de este modo. ¡Serle indiferente a la Patria mostrará que me ama a mí!... Cuán engañado está si cree que éstos son mis sentimientos! [...] (347) ${ }^{9}$

La joven Soledad, desde la retaguardia actúa como una verdadera "madre de la patria” que, en los momentos decisivos, sabe que su pasión amorosa no puede obnubilar la percepción de la realidad. Más adelante se demostrará que ella no estaba engañada: la conducta confusa de su amado provenía de la falta de noticias en la que ella misma se tenía que mover.

7 "12 de julio [1854] [...] Las ocho de la noche. Las cosas políticas van mal, malísimamente esta noche. Anoche parece que se escapó Obaldía y andaban hoy todo el día buscando al Sr. Logan que lo ayudó a salir. [...] Acabo de recibir un papelito de Mary en que me dice que hay mucho movimiento y agitación en las calles [...]. El gobierno usurpador dicen que se ha decidido a darle el pasaporte a Mr. Green, Ministro de los Estados Unidos. A ellos qué les puede importar que los Yankees nos declaren la guerra. ¡Desgraciado país! ¿Y habrá quién esté indiferente en medio de su Patria que corre hacia la ruina?... ¡Dios mío!, cuán amarga es la copa del dolor que tengo que tomar. [...]” (320).

8 “11 de noviembre [1854]. [...] Gritaban “¡Viva el General José María Melo!”, y lo que me divirtió fueron los gritos de “¡Viva la Monarquía!”... ¡Pobres ignorantes que no saben lo que dicen!” (578).

9 Quizá conviene señalar ya que los tres asteriscos (***) sustituyen en la versión impresa a "un símbolo parecido a una Z” que la autora utiliza inicialmente para referirse a José María Samper (según informa la editora, XXVII).

Revista Iberoamericana, Vol. LXXVI, Núms. 232-233 Julio-Diciembre 2010, 913-937 ISSN 0034-9631 (Impreso) 
Pero quizá la consecuencia más interesante que tiene la guerra respecto de la escritura de Soledad Acosta es que la convierte en una narradora de batallas: por dos veces encontramos minuciosas escenas bélicas: el 25 de noviembre de 1854 (428-434) y el 6 de diciembre de ese mismo año (439-444). En ellas revela la autora un sostenido esfuerzo estilístico: verbos de "ver" que subrayan el punto de vista; alternancia del pasado con el presente verbal, incertidumbre sostenida, destacando el papel piadoso de las mujeres ("nosotras gritamos todas que lo dejaran vivo pero que si querían que lo amarraran”, 443). El cierre triunfalista de esa descripción funciona como un verdadero epifonema: "Por fin estamos libres... Por fin llegó el día en que nos vimos otra vez en una ciudad de Republicanos y cayó la tiranía al presentarse los bravos defensores de la libertad. [...] ¡La Nueva Granada ha mostrado que merece ser libre y que un Dictador jamás podrá existir aquí! [...]” (439). Después, como dije, el orden vuelve al mundo, un mundo en el que, por fin, podrá llegar también a término la íntima guerra de amor.

¿UN TEXTO SIN CONTEXTO?

Si interesante resulta la lectura "simplemente” histórica del diario de Soledad Acosta, más aún lo es una lectura histórico-literaria. A mediados del siglo xix, la literatura y la historia, en Colombia -como en casi toda Hispanoamérica- son asunto de unas pocas familias, estrechamente ligadas entre sí. Esas familias suelen pertenecer a la alta burguesía criolla, conservadora y católica, que ocupa la mayor parte del espacio público y se resiste a cederlo a otros protagonistas. Si esa resistencia está detrás del conflicto bélico que Soledad Acosta relata en su diario, otras resistencias atraviesan también el espacio cultural en el que surge esa escritura y el diario levanta acta de las tensiones y contradicciones del proceso de expansión del campo.

En el caso de intentar una lectura histórico-literaria de ese tipo cabría preguntarse qué antecedentes para este diario existen en el ámbito hispanoamericano, qué modelos menciona la autora o qué conciencia tiene ella de la importancia de la escritura íntima en la "educación de las señoritas”. Todo ello revelaría no pocos aspectos que hacen del diario de Soledad Acosta un texto singular.

En el ámbito de lo literario, Acosta es casi estricta contemporánea de Rafael Pombo o Jorge Isaacs en Colombia; de Juan Montalvo y Juan León Mera, en Ecuador; de Ignacio Altamirano y José Riva Palacio en México; o, por fin, de Ricardo Palma, en Perú. Hay que considerarla, entonces, como miembro de lo que suele llamarse "segunda generación romántica” hispanoamericana (Oviedo), aunque en el momento de la redacción del diario, si nos atenemos, a la generosa confesión de lecturas, ninguno de estos autores estaba en el horizonte de la joven.

Si para aquilatar la ampliación de ese campo cultural, atendiendo al espacio propiamente femenino, el marco contextual se restringe a la escritura de mujeres,

Revista Iberoamericana, Vol. LXXVI, Núms. 232-233 Julio-Diciembre 2010, 913-937
ISSN 2154-4794 (Electrónico) 
Acosta es una generación más joven que Gertrudis Gómez de Avellaneda (Cuba, 18141873) o Juana Manuela Gorriti (Argentina, 1818-1892), dos de las autoras clave en la escritura de lo íntimo en Hispanoamérica, "románticas" que, si bien practicaron una escritura autobiográfica intensa (Prado) no se ciñeron, sin embargo, al marco diarístico en la forma que lo hizo Acosta. ${ }^{10}$ Pero ninguna de estas escritoras es mencionada en el diario de Soledad Acosta, como tampoco lo son los textos más antiguos de la intimidad femenina hispanoamericana, que acaso hubiera podido Acosta conocer en francés: las obras de la Condesa de Merlin (María de la Merced Beltrán de Santa Cruz y Montalvo; Cuba, 1789-1852) ${ }^{11}$ o, quizá las memorias de Flora Tristán (Francia-Perú, 1803-1844). ${ }^{12}$

Desde luego, no pudo conocer tampoco los diarios de alguno de sus contemporáneos, como los del puertorriqueño Eugenio María de Hostos (1839-1903). ${ }^{13}$ Por su extensión, éstos resultan incomparables con el de Acosta: Hostos los escribe durante casi toda su vida, con una sola interrupción importante; Acosta confiesa haber empezado a llevar un diario durante su estancia parisina en 1847 (diario que ella aún conserva y consulta en 1854-vid. luego-, pero que al parecer se ha perdido) y tras su matrimonio con José María Samper en 1855 no volvió jamás, hasta donde se sabe, a practicar esa escritura, aunque sí revisó su "segundo" diario, al parecer en 1864, e intentó un ejercicio memorialístico en 1875, que no pasó de una evocación de infancia. También Hostos realiza en 1874 un ejercicio semejante, limitado a la infancia, que tiene la particularidad de ir redactado en $3^{\mathrm{a}}$ persona. ${ }^{14}$

El grado de intimidad resulta incomparable entre ambos textos, por otra parte: los diarios del puertorriqueño son los de alguien ya maduro (al menos desde las fechas que se han conservado), que quiere ejercer un papel importante en el proceso de

${ }^{10}$ El supuesto "diario de amor" de Gómez de Avellaneda no es sino un texto ficticio a partir de las cartas enviadas a Ignacio Cepeda. El de Acosta sí es verdadero "diario de amor", aunque mucho menos apasionado que aquellas cartas, igual que su personalidad resulta para esas fechas mucho menos definida que la de la cubana. En tal sentido, podría resultar interesante cotejar las referencias al propio talento de una y otra en los textos de referencia. Lo íntimo de Juana Manuela Gorriti, redactado entre 1876 y1892 no se ajusta de modo tan estricto a la definición del diario, sino más bien a la de memorias fragmentarias, con indicaciones ocasionales de fecha (Mizraje). En cualquier caso, esos textos se dieron a conocer mucho después de la redacción del diario de Acosta: 1893 es la fecha de publicación de Lo íntimo de Gorriti; 1905, la fecha de publicación de la Autobiografía y cartas de Avellaneda.

${ }^{11}$ Mis doce primeros años (en francés; ca. 1831; trad. en 1838); Souvenirs et mémoires de Madame la Comtesse de Merlin, publiées par elle même (1836); Viaje a La Habana (1844; cartas). Datos en Prado.

${ }_{12}$ Peregrinaciones de una paria (memorias, 1838). Para el contexto de estas obras, cfr. Mataix.

${ }^{13}$ Escritos entre 1858-1878 y entre 1898-1903 (aunque sólo se conserva desde 1866), pero no publicado hasta 1939, se ha tenido hasta ahora como el ejemplo más antiguo de diario "íntimo" hispanoamericano (Mora). Otros diarios masculinos, contemporáneos o más antiguos, no son pertinentes, aunque tampoco son citados por Acosta, por tratarse de diarios de viaje o diarios políticos (como el del chileno José Victorino Lastarria, que abarca entre 1849 y 1852, pero no se publica, al parecer, hasta 1917).

${ }_{14}$ Ambas "memorias" se incluyen en las respectivas ediciones que manejo.

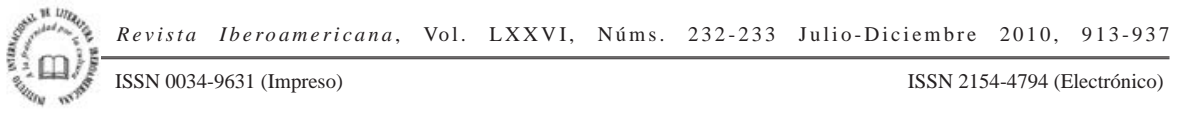


emancipación de Puerto Rico y Cuba, y sabe cómo hacerlo, entrando en contacto -por ejemplo- con los republicanos liberales durante la revolución de 1868 en España, un proceso que resulta un contexto adecuadísimo para sus propias aspiraciones políticas. No obstante, esas páginas de Hostos están plagadas de inmensas dudas y vacilaciones sobre el proyecto literario y vital. Son diarios de “queja” y autoanálisis, centrados sobre todo en la conciencia de crisis y soledad que le embarga durante su estancia en Europa. Verdadero recuento de ocupaciones y preocupaciones, el relato incluye numerosas reflexiones morales a veces en forma aforística.

Frente a ese (imposible) parangón, los diarios de Acosta son un texto de jeune fille: la transcripción de las tribulaciones de una "mocita" colombiana, en un periodo de crisis personal y tensión política -como se ha dicho-, marcada por la muerte del padre y por unas aspiraciones intelectuales que quiere imponer, aunque no está segura de conseguirlo sin la ayuda de un interlocutor privilegiado, que encontrará en la figura del que habrá de ser su esposo.

Para terminar de comprender la singularidad del diario de Soledad Acosta, no puede olvidarse tampoco que es un diario preliminar: está escrito (y finalizado) antes de toda su obra. Este diario es obra singular de una autora que será canónica (y muy prolífica), aunque todavía no es escritora en el momento de escribir ese diario. Su obra pública comienza verdaderamente después de casarse y cerrar el diario. Por eso, el diario podría adscribirse, a posteriori, a la "prehistoria" de una escritura multigenérica, pues es en sus páginas donde Acosta se declara y se prueba, absolutamente, como escritora. Ahí están sus primeros atisbos ficcionales (traducciones de cuentos, transcripción de relatos orales, ficcionalización de experiencias), sus primeras reflexiones de tipo ensayístico sobre la condición femenina (si bien fragmentarios), sus primeros ejercicios históricos (el relato del golpe de estado de Melo), y, tal vez, sus primeros y únicos poemas. ${ }^{15} \mathrm{Su}$ diario es, verdaderamente, ensayo de una escritura, que -inversamente- se adoptará como forma en algunos de los textos ficticios que la escritora dará a la luz años después (Dolores, La monja, Una holandesa en América). ${ }^{16}$

${ }_{15} \mathrm{Al}$ parecer no publicó poesía. En el diario aparecen poemas no atribuidos a autor alguno que, a veces, la editora considera escritos por Acosta: "De ser así, este diario contendría las únicas incursiones de la autora en este género" (34 n.).

${ }^{16}$ Los dos primeros títulos se incluyeron en la recopilación que de sus primeros escritos hiciera su marido en 1869 (Novelas y cuadros de la vida sur-americana). El tercero permanecía inédito desde 1888, pero se ha reeditado en 2007 (Casa de las Américas y Universidad de los Andes). Quizá conviene recordar que también Hostos adopta esa "plantilla" diarística cuando compone una de sus primeras novelas: $L a$ peregrinación de Bayoán (1863).

Revista Iberoamericana, Vol. LXXVI, Núms. 232-233 Julio-Diciembre 2010, 913-937
ISSN 2154-4794 (Electrónico) 
DiARIO DE LECTURAS

Así las cosas, el diario de la joven colombiana se convierte en un texto pionero en la Hispanoamérica, un texto singular y sin modelo (al menos hispano), cuya tradición no está, desde luego, en el espacio en el que surge. Dada la formación francesa de Acosta durante los años de residencia parisina entre 1847-1850, cabría imaginar que la escritura de un diario está relacionada más bien con aquella tradición pedagógica: de hecho, Soledad confiesa haber llevado uno durante aquellos años, ${ }^{17}$ y el que actualmente puede leerse corresponde exactamente con el modelo del diario pre-nupcial tan frecuente en el ámbito francés (Lejeune).

Pero como desde muy pronto el diario de Acosta se orienta hacia la práctica literaria, en su escritura opera de modo muy claro la imagen de la literatura que Acosta se construye a partir, necesariamente, de sus lecturas, éstas sí cartografiadas minuciosamente en las páginas del diario. Lo primero que hay que decir es que Acosta es una lectora privilegiada: trilingüe, su ser amplía sus lecturas tanto como sus lecturas forman su carácter. Pocos lectores (y, desde luego, muy pocas mujeres) de su entorno podían tener en su tiempo un horizonte de lecturas tan amplio como el de Soledad Acosta.

El trasfondo de esas lecturas es básicamente romántico, aunque también lee a clásicos latinos -Virgilio- o franceses -Molière-. Al lado de los infaltables Lamartine y Chateaubriand (a los que dedica una nota comparativa), ${ }^{18}$ que cubren la máxima amplitud de su horizonte ideológico (cristianismo y libertad), durante la guerra civil de 1854 lee y cita profusamente a Byron en inglés (350). Otros autores anglosajones que le gustan son Washington Irving (170), el poeta Thomas Moore o, por encima de todos, Benjamín

17 “7 de abril [1854] Estuve leyendo mi diario de cuando estaba en el colegio en 1847. Qué triste pasaban mis días allí, suspirando sin cesar por mi patria amada pasaba los días, ... sin tener con quien congeniar... [...]” (195).

18 "21 de junio [1854]. [...] Las diez de la noche. He estado leyendo las memorias de Chateaubriand. Mucho me agrada su estilo poético filosófico mezclado de una melancolía solemne. Educado sobre las rocas del mar, teniendo delante de sus ojos diariamente este elemento tan bello, tan grandioso y solemne, con su mugir terrible algunas veces y el movimiento compasado de las olas sobre las rocas en tiempo de calma: este Océano tan vario cambiando de faz por momentos pero siempre poético y hermoso, esta contemplación desde niño de la Obra más grandiosa del Creador, formó el carácter de Chateaubriand. Los niños que tienen padres severos se acostumbran a pensar y esto madura el carácter muy temprano. Su casa no era para él un lugar de sosiego y de amor. La melancolía orgullosa de su padre y el genio de su madre le hicieron el hogar doméstico terrible, y parte de su vida la pasaba sobre las playas de Saint-Malo. ¡Qué diferente la infancia de Lamartine! Su felicidad estaba en su casa, y su madre con su poesía y amor fundó aquella dulzura en el estilo de este gran poeta, cuyos sentimientos son tan delicados como los de una mujer. Yo no sé por qué recordé ahora a mi poeta favorito, ¡Lamartine! El divino Lamartine, ¡como dice mi bien! Chateaubriand, el defensor del Cristianismo, y Lamartine, el de la libertad!” (295-296). Unos días después vuelve a ponderar a Chateaubriand: "22 de junio [1854]. He seguido leyendo las Memorias de Chateaubriand. Me interesan y me dan fondo para reflexionar mucho. [...]” (296).

\begin{tabular}{l} 
Revista Iberoamericana, Vol. LXXVI, Núms. 232-233 Julio-Diciembre 2010, $913-937$ \\
\hline ISSN 0034-9631 (Impreso)
\end{tabular} 
D'Israeli, de quien menciona varias novelas (sobre todo en los primeros meses del diario: Coningby, or The New Generation, 1844; The Rise of Iskander, 1833), algunas de ellas con comentarios realmente interesantes para entender la función y concepción de la lectura: Contarini Fleming. APsycologicalAutobiography (1832) le parece, por ejemplo, un reflejo de la historia del primer matrimonio de Samper, frustrado por la muerte ("18 de octubre [1853]. [...] Cuán parecida su historia, su poesía, su imaginación, su talento, todo, todo se parece [...]”, 37). Otra novela de D’ Israeli le sirve para aquilatar una cierta representación de lo femenino, de la que ella misma se excluye, con una valoración del lugar de la mujer en la sociedad:

9 de noviembre [1853]. [...] Estuve esta tarde leyendo a Henriette Temple [1837]. ¡Qué escenas se encuentran en este libro!... ¡Estoy segura que no se debía dejar leerlo a muchachas de imaginación viva, exaltada, porque aunque no tenga nada de malo, una muchacha sin experiencia creería que todos los hombres son como Fernando Armin y se convencería de que ellas debían hacer todo lo que hace la heroína! En la vida y como está organizada la sociedad sería imposible. Es solamente en Inglaterra, el país clásico de la libertad de las mujeres, que se ven tales cosas. [...] (62)

No faltan otros grandes nombres de la literatura romántica europea en estas páginas: a Schiller (169) lo cita en español-probablemente traduciéndolo directamente del francés o el inglés-; a Heine (352) lo cita en inglés.

Son muchos menos los autores españoles o hispanoamericanos queAcosta menciona: Espronceda (para comparar la Elvira del Estudiante de Salamanca con la esposa muerta de Samper, 40) o Zorrilla $(488,499)$, además de la mención de haber asistido a una representación de Los amantes de Teruel de Hartzenbusch, cuya trama, desde luego, proyecta sobre su propia pasión (1/3/1854, pp. 142-143). Entre los españoles parece interesarle más el neoclásico Juan Bautista Arriaza, a quien se cita en varias ocasiones $(38,63)$.

Sorprende, quizá, la ausencia de cualquier autor hispanoamericano, lo que sin duda puede valer como testimonio de la escasa comunicación literaria continental en ese momento. Ni siquiera las obras de algunas de las autoras que abren camino a la escritura femenina hispanoamericana-como ya se dijo-parecen estar entre las lecturas de Soledad. No se cita ni siquiera a Gómez de Avellaneda, cuya novela Sab (1841) le hubiera revelado el horror de la esclavitud antes que la obra mucho más conocida de Harriet Beecher Stowe de 1852, que lee pronto y cita con sorpresa en las primeras páginas de su diario: "18 de septiembre [1853] [...] Estoy leyendo el Tío Tom, libro tan popular en todo el mundo; verdaderamente es una cosa horrible la esclavitud, nunca la había yo mirado bajo este aspecto” (16).

Revista Iberoamericana, Vol. LXXVI, Núms. 232-233 Julio-Diciembre 2010, 913-937
ISSN 2154-4794 (Electrónico) 
Mucho más familiares le resultan textos clásicos de la literatura "femenina”, como la Corinne ou l'Italie, de Mme. de Staël (1807),${ }^{19}$ texto que le sirve para consignar también alguna información sobre sus hábitos lectores (o sobre la disponibilidad de obras):

7 de enero [1854]. He seguido leyendo a Corinne que me gusta mucho. La comencé a leer en español y estoy siguiéndola en francés. [...] ¡Corina! ¡Cómo explicar mis sentimientos!, tan tormentosos. Qué entusiasmo corre por mis venas al leer este libro. Todas las palabras las encuentro frías, sin sentido para explicarme. [...] Pero cuando veo mis sentimientos, mis emociones más secretas explicadas por la pluma de Mme. de Staël, vuelve a revivir mi entusiasmo [...]. (115-117)

En Germaine Necker encuentra Soledad, entonces, un modelo de la elocuencia que ella echa de menos en su propia escritura. Quizá por eso, sigue leyendo otros textos de la misma autora en esa misma época, textos en los que de nuevo encuentra consonancias con su estado:

1 de febrero [1854]. [...] Estaba leyendo anoche, o más bien, al abrir el libro sobre el imperio de las Pasiones por Mme. de Staël, cayeron mis ojos sobre un pasaje que yo había leído antes pero que nunca me había hecho tanta impresión. Hablando de que ningún ser humano puede ser feliz, dice que si acaso dos personas unidas por el himeneo se encuentran perfectamente felices teman por el porvenir, que teman y que esperen alguna desgracia [...]. (126-127)

A Soledad le interesan, sin duda, las escritoras: citará también a Anne Brontë (Wildfeld Hall, 1843; 418) y títulos recientes en su momento de otras autoras inglesas hoy más raras, pero al parecer de gran éxito en su momento, lo que indica la atención que Soledad prestaba a la literatura europea contemporánea. ${ }^{21}$ Además de las mencionadas

${ }^{19}$ La primera edición de Corinne en español es de 1819. De su importancia en las románticas españolas e hispanoamericanas ha hablado Kirkpatrick (85).

${ }^{20}$ Se refiere sin duda a De l'influence des passions sur le bonheur des individus et des nations (1796); aunque hay una traducción de 1827, probablemente Acosta traduce directamente del original, como unos días después: "13 de febrero [1854]. [...] Mme. de Staël dice que un grande afecto, un amor verdadero está siempre unido con la melancolía... [...]” (137).

${ }^{21}$ Me refiero a títulos como el cuento o novela Zingra, the Gipsy, de Annette Marie Maillard (1852): "Estoy" leyendo un cuento bien interesante llamado Zingra" (29/7/1854; 334; datos en http://www.soi.city. ac.uk/ asp/v2/authors/authorfiles/tget.cgi?1280.html@Zingra,theGipsy) o una novela de Lady Emily Ponsonby (1817-1877), de 1850, que de nuevo es reflejo de su situación: “6 de diciembre [1853]. Estoy leyendo un cuento o novela que llaman Pride and Irresolution. Hay partes en ella que me recuerdan emociones pasadas. Porque todo lo que leo, todos los caracteres de que oigo o leo, siempre, siempre, aun sin pensarlo, los comparo a ***. No encuentro gusto si no tienen algo que imagino que se parece. [...]" (97)

\footnotetext{
Revista Iberoamericana, Vol. LXXVI, Núms. 232-233 Julio-Diciembre 2010, 913-937 ISSN 0034-9631 (Impreso) 
sólo citará autoras colombianas: Agripina Samper, hermana del que será su esposo (y de cuya habilidad versificadora duda, para atribuirla al hermano; 14) o la más conocida Josefa Acevedo (1803-1861), de quien, significativamente, cita un poema dedicado a Elvira, la esposa muerta de Samper (27/7/1854; 331-332), revelando que la existencia de la mayoría de los sujetos importantes del diario está filtrada por la textualidad.

Entre las ausencias de este catálogo de lecturas llama la atención la de la prensa hispánica: no hay referencia a ningún periódico o revista de eseámbito (fuera deColombia). Quizá tampoco llegaba esa prensa a Bogotá, algo que hubiera sido importante para quien enseguida empezaría a colaborar en prensa colombiana y más tarde fundaría revistas, a menudo orientadas a un público femenino. ${ }^{22}$ Sin embargo, sí lee prensa europea, aunque, al parecer, no muy actual: El Correo de la Europa, gaceta anglo-francesa (1776-1792), de donde saca cuentos para traducir ("La última hada", 25-33) o la revista francesa Le Magasin Pittoresque (1833-1938; 45, 53), que también parece tomar como motivo para ejercicios de traducción.

Los únicos periódicos hispánicos que menciona son los que tiene más a mano: los colombianos (El Pasatiempo, El Tiempo), de donde transcribe, además de noticias, textos literarios publicados a veces por mujeres (Agripina Samper), pero más a menudo por su amado Pepe, quien destaca, por supuesto, por encima de los otros poetas colombianos que le interesan.

EL GÉNERO “DIARIO” Y EL “GÉNERO” FEMENINO

El repaso de las lecturas de Soledad Acosta ha ido confirmando una formación romántica, que tiene un reflejo capital en su imagen de lo femenino y en las líneas de resistencia a esa imagen. Asumir que parte de la singularidad de este diario reside en el hecho de ser un "diario de mujer" implica, desde luego, riesgos: el riesgo de considerar inevitable una lectura marcada por el "género". Carolina Alzate establece como punto de partida de su acercamiento al diario de Acosta una lectura semejante, al proponer que se trata de un ejemplo de "lo marginal dentro de lo marginal" (Alzate 2005) y, aunque no explica los términos de esa "abismación", cabe comprender que se trata de una abismación genérica en sus dos sentidos más o menos habituales: marginal por diarística (sub-género de la autobiografía) y doblemente marginal por femenina.

Sin embargo, el planteamiento puede ser matizado. Si asumimos, con Alzate y gran parte de la teoría autobiográfica feminista, que el género “elevado” de las memorias o

${ }^{22}$ En 1858 comienza a mandar colaboraciones a la prensa colombiana desde París; en 1862 funda la Revista Americana con su marido. En 1878 empieza a publicar La Mujer (hasta 1881), primera revista colombiana escrita sólo por mujeres. Más tarde fundará otras revistas “familiares”: La Familia, Lecturas para el Hogar (1884-1885); El Domingo de la Familia Cristiana (1889-1890) o Lecturas para el Hogar (1905-1906). Datos en la cronología que precede a la edición.

Revista Iberoamericana, Vol. LXXVI, Núms. 232-233 Julio-Diciembre 2010, $913-937$
ISSN 0034-9631 (Impreso) 
incluso de la autobiografía (habitual entre los sujetos masculinos del xix) estaba vedado a las mujeres -en ese momento- porque contradecía la auto-/ ab- negación que se suponía propia del sujeto femenino, el único género para la expresión de la subjetividad que queda disponible a las mujeres de la época es el género más íntimo: el diario o la carta. No obstante, la decisión de llevar un diario puede interpretarse como un gesto dialéctico: el diario se convierte así en "negación de la negación”, en negación de aquella “(auto / ab)negación” femenina recién evocada. El diario femenino supera dialécticamente (asume y lleva más allá23 ${ }^{23}$ el riesgo de aniquilación del sujeto femenino decimonónico.

Aunque tampoco tengamos demasiadas muestras para el ámbito hispanoamericano, es obvio que también los hombres practicaban ese género "marginal", pero en su caso la escritura del diario parece poder interpretarse como una "afirmación" de la subjetividad pura (frente a la "afirmación” contrastada que podrían permitir memorias y autobiografías) y no una doble negación, como se sugiere para el caso de las mujeres. Por ello, la escritura diarística femenina cobra signo de resistencia y rebeldía, algo que no es tan evidente en el caso masculino.

Esto, que quizá se hace más claro cuando el diario es el de una escritora que aspira a la publicación -de textos distintos del diario por lo general, y desde luego para el XIX hispanoamericano-, permite leer de otro modo los “diarios femeninos”, al margen de la tradición que considera dicho sintagma una especie de pleonasmo, que ve en el género diarístico algo intrínsecamente femenino, por íntimo y cotidiano (Hogan, Didier).

De este modo, si aceptamos no eludir una lectura "genérica", podremos, al menos, plantearnos cuestiones nuevas. La inscripción de texto marcado "genéricamente" es explícita en el diario de Soledad Acosta, y su editora, por lo general, realiza una intervención enfática, mediante notas que subrayan la anticipación de preocupaciones “feministas” en estas páginas. De hecho, el énfasis aparece ya en el prólogo, cuando Alzate afirma: "Hay que señalar que ya en este texto temprano se encuentran los temas que van a ocupar a la autora a lo largo de su carrera intelectual: el de la patria y el de las mujeres” (XX). Se anticipa así una lectura prospectiva del diario (que, en efecto, se verá confirmada por gran parte de la escritura posterior de Acosta ${ }^{24}$ ), con implicaciones políticas, que no podrán ser soslayadas.

Pero antes de llegar a ese punto, cabe plantearse otras preguntas. Dos, por ejemplo, surgen de inmediato: en primer lugar, ¿hasta qué punto encaja este diario dentro de los

${ }^{23}$ Podría sugerirse que en él hay una vía para la Aufhebung hegeliana de esa situación. Duque propone traducir el término como "asunción”: "Aufheben significa a la vez suprimir, conservar y elevar. [...] Se ha elegido el verbo "asumir” porque: 1) implica en castellano un "hacerse cargo”, y no un abandono (como parece sugerir "suprimir”) ni un "ir más allá” de la cosa considerada (como en "superar” o "sobrepasar”) [...]” (Duque 327-328n).

${ }^{24}$ Además de sus novelas, se piensa en textos de carácter ensayístico como La mujer en la sociedad moderna (1895), que no he podido ver.

Revista Iberoamericana, Vol. LXXVI, Núms. 232-233 Julio-Diciembre 2010, 913-937 
parámetros de la "escritura femenina”? En segundo lugar, y en relación con la respuesta que se dé a lo anterior, cabe preguntarse también de qué modo el diario de Acosta desestabiliza el modelo de "escritora hispanoamericana del xIX" (diferente, digamos, del reconocible en Gómez de Avellaneda, por ejemplo).

En cuanto a lo primero, rasgos como la atención al "detalle” o los índices de "domesticidad” (Hogan), no parecen ser característicos del diario de Acosta. El suyo es un diario introspectivo en el que la descripción de lo exterior apenas importa durante muchas de sus páginas. Acosta no deja demasiado hueco a las actividades domésticas y desde luego tampoco es rica en la transcripción de rasgos del modelo del "ángel del hogar", quizá porque en ese momento no tiene "hogar propio" y no termina de encontrarse a gusto en el hogar que habita (el de la familia, dirigida por la madre). Casi cabría decir que la única actividad doméstica que a Soledad Acosta le interesa consignar en su diario es la lectura: leer (y escribir) son sus quehaceres principales cuando está en casa. La visita (recibida y rendida) es la otra actividad cotidiana más consignada en el diario hasta el momento del estallido de la revolución, en abril de 1854: fuera de la lectura, las escenas más domésticas son instantáneas que podríamos llamar de "baile o balcón”. Antes del golpe de estado, la vida exterior de la joven colombiana es plácida y el tiempo pasa en ceremonias de la hospitalidad y la sociabilidad. De hecho, cabría decir que la motivación remota del diario surge durante unas fiestas: las de Guaduas de agosto de 1853, en las que verá por primera vez a José María Samper. La evocación de esas fiestas será un leit-motiv del diario y la "fiesta menor" que es el baile privado parece funcionar en ocasiones como "metonimia" de aquel encuentro, igual que los pretendientes en esos bailes o en otras visitas, son "imagen negativa" del amado. $Y$ aun habrá otra metonimia de escala más reducida: si el baile era un encuentro privado colectivo, la visita particular del amante, en las últimas fases del noviazgo, supondrá la quintaesencia de aquel encuentro primigenio.

Pero esos hábitos doméstico-festivos, propios de su clase, entablan desde el principio una relación conflictiva con la que es, como digo, la principal actividad hogareña de Acosta, la lectura y la escritura:

2 de noviembre [1853]. Ayer no escribí, no tuve tiempo. Virginia estuvo aquí todo el día con su madre. Por la noche vino Vicente y Mariano y bailamos hasta las diez, así que no tuve tiempo de pensar y mucho menos en escribir. [...] (53)

12 de diciembre [1853] ¡Cuánto tiempo hace que no escribo! Se pasan los días y no pienso en nada de provecho. Bailes, diversiones y boberías ocupan mi tiempo aunque no mis pensamientos. [...] (103)

Cuando no puede escribir, Acosta se queja, y lo hace a menudo porque reconoce que escribir es el único modo de manifestar su diferencia, la singularidad que la aparta

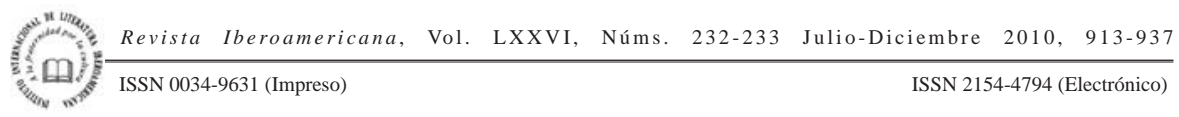


del modelo asumido en su ámbito como "femenino". Lo propio de "las chicas de su clase y de su edad” son, a su juicio, "boberías”. En tal sentido, el diario sí que proyecta un rasgo romántico-femenino (doblemente romántico, quizás): el sentimiento de alienación respecto del universo que rodea al sujeto (Kirkpatrick 37). Soledad Acosta se siente marcada por su nombre: aislada en medio de un espacio social que no entiende su singularidad, que no le ofrece los medios para desarrollarla (especialmente tras la muerte de su padre). Ciertamente, esa conciencia es identificada con la condición femenina en una entrada clave:

11 de septiembre [1854]. [...] ¡La sociedad, la sociedad! No poder vivir como uno quiere, no poder decir, ni siquiera sentir sus penas, sus alegrías... Nada, todo tenemos que encubrirlo, todo tenemos que esconderlo a los ojos del mundo y con falsa sonrisa seguir viviendo con todos nuestros sentimientos artificiales, ¡nada hay verdadero! ¡Y cuán pocas veces podemos decir lo que sentimos!... Dicen que las mujeres no son sinceras, que no hablan casi nunca lo que verdaderamente sienten. ¿Sin embargo qué otra cosa podemos hacer? Todo lo que hacemos, lo que decimos y aun lo que pensamos es causa de crítica para los demás. ¡Y decimos que hay en el mundo libertad! Adonde está la libertad si siempre nos hallamos esclavas de la sociedad, sin esperanza de poder huir de ella jamás... [...] (389-390) ${ }^{25}$

Es un momento en el que ha entrado en crisis ya el mundo antiguo. Tras el golpe de estado (17/4/1854), la domesticidad cambia necesariamente y ya no volverá a ser la misma. La casa se ve invadida por la guerra y, en cierta ocasión, habrá de ser abandonada para refugiarse en un convento. Lo privado se hace público. Son los únicos días en que vemos a Soledad Acosta ocuparse -colectivamente- de labores "propias de su sexo": con otras mujeres, borda cintas para los soldados (394 ss.), tarea “cívica” que no termina de satisfacer la aspiración a hacer "obra noble” que Acosta sentía como destino propio desde tiempo atrás:

11 de noviembre [1853]. [...] Son las ocho de la noche. Qué día el que he pasado. ¿Qué he adelantado? Nada. ¿Cuáles son los pensamientos dignos de inscribirse en las hojas del libro del tiempo? ¿Cuáles los hechos? ¡Ningunos! Así pasan los días sobre mi cabeza sin saber qué se han hecho. ¿Para qué me hizo Dios inteligente? ¡Para qué todos mis sentidos si no han de servir para el bien de mi alma y de la humanidad! ¿Pero qué puede hacer una mujer? Mi conciencia me contesta: si no puedes hacer obras nobles, hechos

${ }^{25}$ Interesa también esta referencia: “31 de mayo [1854] [...] También fuimos a donde María G. pero no la vimos. Anoche a las dos de la mañana le nació una niñita, lo que sienten mucho. Deseaban que fuera hombre, pero así sucede: siempre nos reciben a las pobres mujeres en el mundo malísimamente. Y tienen, razón, que es la suerte de las esclavas. [...]” (271).

Revista Iberoamericana, Vol. LXXVI, Núms. 232-233 Julio-Diciembre 2010, 913-937 
dignos de memoria por tu sexo y tu corta inteligencia, puedes hacer la felicidad de las personas que te rodean. [...] (69)

Soledad se debate entre esa proyección colectiva (las obras nobles, “no femeninas”) y la (aparentemente asumida) dedicación a las actividades que como mujer le eran lícitas (lo más cercano al "ángel del hogar” que se ve en el diario). Tal será la tensión que caracterice la trayectoria de Acosta: dedicarse a "hechos dignos de memoria” o a la "felicidad de los próximos”, a lo "público" o a lo "privado”. Con la guerra, surge la oportunidad de volcarse un poco más hacia el polo primero de esa oposición: no le basta con bordar cintas; siente que puede colaborar de un modo singular y decide escribir para el público, para las otras mujeres, una proclama, en la que, diciendo lo que siente, intenta hacer “obra noble”, saliendo del estado de melancolía característico de una mujer de su clase, de su edad y en su situación:

9 de junio [1854]. Algunas veces me exalto, olvido por un momento mis pesadas penas y me entusiasmo. Converso con energía y dejo aquella apática melancolía que me oprime el corazón. Pero qué poco dura este estado. [...] Esta tarde estuvimos en casa de las Orrantia. Allí se habló de que esta revolución jamás se acabaría y yo por chanza dije que me pondría a la cabeza de las mujeres y acabaría con todos los enemigos. Volví a casa y a instancias de mi mamá, y curiosa de ver si yo también podría escribir una proclama, la hice. Pero antes de acabar de escribirla se me acabó el entusiasmo y la transitoria excitación pasó, iy volví a quedar tan melancólica y sin esperanza como antes! [...] (284)

Sea como fuere, "por chanza" o a instancias de una madre que en pocas ocasiones sintoniza con la hija, la proclama "a las valientes bogotanas" se concluye y manifiesta a la vez su compromiso político-patriótico y una relación “de género” conflictiva en la medida que se sugiere que las mujeres han de adoptar un papel más activo en el momento en que los hombres parecen haber abdicado del rol que les correspondería por su sexo (pp. 587-588). El 10 de junio de 1854, Soledad firma en Bogotá el siguiente texto, que no se sabe si se llegó a publicar:

¡Compatriotas! ¡Nuestra infeliz patria marcha con pasos precipitados hacia la ruina, el sol de la esperanza se oculta bajo la sombra de la desgracia! ¡Los héroes de otros tiempos pierden la confianza v la victoria nos deja para proteger el pabellón enemigo! ¡Mujeres valientes, de todas las clases de esta ciudad! Aquellos destinados por la naturaleza para protegernos abandonan sus hogares y el valor no los anima ya: ¡nos dejan! ¡Huyen olvidados de que quedan sus familias sin varón que las proteja!

¡Conciudadanas! ¡Levantad vuestras tímidas cabezas, fortaleced vuestros débiles brazos y marchemos a atacar a los vándalos que se’ han apoderado de esta Ciudad! ¡No temáis! ¡Que es más honroso morir por la patria que vivir esclavas de los hombres más

Revista Iberoamericana, Vol. LXXVI, Núms. 232-233 Julio-Diciembre 2010, 913-937
ISSN 2154-4794 (Electrónico) 
inicuos! ¡Qué!, ¿̇los asesinos y traidores nos seguirán gobernando?, ¿la paz de nuestras casas se acabará por ellos? ¡No! ¡Yo ofrezco llevar a la Victoria a todas las que quieran marchar bajo mis órdenes!

¡Compañeras! Corramos a las armas! ¡Demos una lección a los que se titulan la parte valiente del género humano, mostrando que si podemos ser sumisas también el bello sexo tiene valor y energía!

¡Mirad! ¡El ángel de la muerte se acerca hacia los perversos, y las mujeres son la salvadoras de su patria! (587-588)

De esa proclama, interesa la inversión de rasgos: de “ángel del hogar”, que borda cintas y se ocupa de la felicidad de los suyos, la mujer se convierte casi en instrumento del “ángel de la muerte”. Mostrar su valor y energía supondrá liberarse de una esclavitud segura. Esos rasgos no están reñidos, sin embargo, con la "sumisión” propia del "bello sexo". ${ }^{26}$

Pero es, apenas, un espejismo, como indicaba el propio diario: la domesticidad volverá al interior de las casas tras la guerra, pero, para el caso de Soledad Acosta, estará ya ocupada plenamente por Samper. A partir de ese momento (9/12/1854) son frecuentes las transcripciones de veladas compartidas con el amado leyendo, bailando o escribiendo (444 ss.), veladas que conducen, necesariamente al matrimonio, a la culminación de un modelo tradicional de lo femenino.

Lo cierto es que no son extraños los pasajes del diario en los que Soledad Acosta parece asumir plenamente los rasgos tópicos del modelo femenino vigente en su momento. Algunos ya han sido vistos, como la imposibilidad de alcanzar una proyección pública. Otros se manifiestan en términos menos patéticos y, por tanto, parecen más profundamente arraigados: la volubilidad y la frivolidad son características que Acosta parece asumir como femeninas sin mayor conflicto:

29 de junio [1854]. [...] Hay que aprovecharnos ahora de sus favores [de la fortuna], porque como ella es mujer y ciega cambia a cada instante -Dios me perdone la opinión que tengo de las mujeres en general- de opinión y propósito. [...] (303-304)

24 de octubre [1854], las diez de la noche. [...] ¿ Se acordará mi bien esta noche de esto?... No, sólo el espíritu sin ocupación seria, sólo el corazón de la mujer puede recordar tales cosas. Porque ellas saben amar exclusivamente, es el único objeto de su vida el amor y ser amadas. El hombre tiene otros pensamientos que dirigen sus ideas, otros deberes a qué atender y pueden olvidar lo que nosotras tenemos continuamente en la memoria. (414)

${ }^{26}$ Resulta, además, significativo que, tras la fecha, la arenga concluya con una indicación indumentaria: “El uniforme es a la Blummer", que, como indica la editora, era "Falda corta, a media pierna con pantalones debajo” y fue introducido por Angélica Jenks Bloomer (1818-1894) como forma de liberar la acción de las mujeres.

Revista Iberoamericana, Vol. LXXVI, Núms. 232-233 Julio-Diciembre 2010, 913-937 
Las “disculpas” ni siquiera llegan a parecer irónicas, sino que actúan como signo de la intensidad con la que el tópico es asumido. No hay duda, pues, de que la intensidad del sentimiento amoroso es mayor en las mujeres y, si algún hombre la manifiesta, eso lo hará más “femenino". Obviamente, tal circunstancia concurre en su amado Samper:

3 de mayo [1854]. [...] Aun sus defectos los amo porque son de él. ¿Podría caber en el corazón del hombre un amor tan desinteresado y tierno como el que abriga el corazón de una mujer? Si hay tal ser, es él el que posee esa cualidad, porque tiene la ternura y los delicados pensamientos de una mujer... [...] (233)

Al respecto, resulta interesante la rememoración de una amistad de infancia, porque parece retrotraerse a un momento en el que la construcción de la identidad del sujeto no estaba aún marcada por la diferencia "genérica”, y porque esa indeterminación actúa todavía como patrón de interpretación del suceso más importante de la vida de Acosta a su juicio hasta ese momento: la relación con Samper. Si éste, en 1854, por “desinteresado y tierno", parece a ojos de su prometida la personificación del andrógino, años antes esa figura tuvo un antecedente: Thérèse Leroux, la amiga preferida de la Soledad niña que estudiaba en París (28/3/1854; 172-174). Por ella sentía Soledad un amor especial “no comprendido" y luego traicionado: "Yo creía haber encontrado en ella un alma entusiasta como la mía, bien [sic; tal vez: “y en”] su talento, una simpatía con mis ideas” (173). El día de su 15 cumpleaños (1848), según Acosta, le confiesa ese afecto. Thérèse no lo comprende y lo divulga: “[...] esta fue la primera piedra del edificio de mi ilusión que cayó” (173). Enseguida interpreta esa pasión “ambigua” (según la nota de la editora) como anticipo de lo que habría de sentir por Samper:

Yo tengo presentimientos, ideas muy raras, y me parece que el afecto mío hacia Thérèse fue porque ella tenía algo de parecido a ***. ¡Ahora es que recuerdo que he visto en él movimientos, cierta expresión a veces que no me era desconocida!.. [...] Por fin he descubierto yo no sé precisamente en qué parte de su figura, pero en la expresión, en los ojos, ... en el modo de mirar... se parece a Thérèse... Qué pensamientos cruzan por mi mente... ¡Tal vez yo la amaba tanto porque tenía el presentimiento de que conocería a uno a quien yo debía entregar mi suerte y que tenía algo de semejante a ella! ¡Idea fantástica, idea rara! Podré algún día confiar... (173-174)

La pasión de Acosta se asienta en arquetipos: el de Samper se anticipó en Thérèse. No lo quiere a él porque se parezca a aquélla, sino que, mágicamente, el flujo sentimental se invierte. Ella misma se pregunta reiteradamente si será el complementario (anteotipo) de Samper, única garantía de que su amor sea eterno. La duda corroe las primeras etapas de la relación, pero en cuanto cree confirmada esa identidad complementaria, su felicidad es total. Esa complementariedad debe ser vista también desde el interior del sujeto:

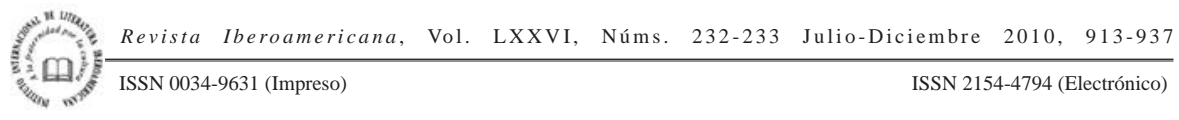


si Samper puede ser figura del andrógino (viril y femenino a la vez), su "anteotipo", Soledad podrá tal vez ser también andrógina: femenina, pero capaz de ostentar virtudes "masculinas”, como la capacidad de realizar "obras nobles".

De ahí que sea interesante también consignar que, más allá de los tópicos románticos sobre lo femenino asumidos por Soledad, hay otros que no aparecen: la primera de las características de la escritora romántica que no encontramos en el diario de Soledad Acosta es el rechazo de los otros a su actividad o a su producción escritural. Simplemente, esto es así porque aún no ha publicado nada todavía. Por mucho que ella proteste de que el lugar que se otorga al talento femenino es limitado, Acosta no puede hablar entonces todavía de "resistencia" a su escritura: al contrario, nadie coarta su afán de estudio (aunque tampoco, tras la muerte de su padre, nadie lo estimule) y sólo las interrupciones de la vida mundana (o de su madre, eventualmente) parecen refrenar ese impulso.

Acosta parece consciente de que las primeras limitaciones a sus logros literarios sólo podrán provenir de su capacidad, en la que tiene una confianza no exenta de dudas. Esas dudas sólo se disipan cuando considera que puede encontrar apoyo explícito en una autoridad externa: la de su futuro marido. Samper cumplirá el papel de estímulo del talento de Soledad y a partir de la formalización de su noviazgo comenzarán una escritura colaborativa que se plasmará también en frutos más o menos públicos. ${ }^{27}$ Ese sometimiento más o menos explícito a la figura del hombre como ratificación del impulso propio (cfr. Arriaga Flórez) limita el alcance de la figura de Acosta como sujeto reivindicativo de la emancipación femenina. De hecho su abundante obra, marcada por el "género", tendrá más bien al parecer ese signo conservador, que en las páginas del diario, sin embargo, todavía es titubeante.

A veces, parece que en esas páginas Acosta se rebela contra tópicos muy arraigados de la visión sexual del xix, como es el desprecio de la fama, algo sólo apetecible al parecer para el varón.

7 de febrero [1855] [...] Las diez y media. Dicen que las mujeres no tienen esa noble ambición de Gloria, que no la comprenden, que amamos pero no comprendemos el amor a la futura fama. Cuán equivocada es esta idea. (488)

Se esperaría que Soledad Acosta iniciase a renglón seguido una defensa de la "ambición” y de la "fama” como objetivos legítimos para un sujeto femenino. Pero lo que viene a continuación inmediatamente es una abdicación palmaria, un sometimiento a un lugar secundario: a las mujeres, la fama sólo les es accesible por "procuración":

${ }^{27}$ Comienzan a escribir juntos El libro de los ensueños de amor: historia poética del bello ideal de la ventura (que la editora transcribe parcialmente como apéndice a su edición); en 1862 fundan juntos, como se dijo, la Revista Americana en Lima; en 1869, Samper edita Novelas y cuadros de la vida suramericana de su esposa.

Revista Iberoamericana, Vol. LXXVI, Núms. 232-233 Julio-Diciembre 2010, 913-937 
¡Yo siento en mí el entusiasmo más grande cuando pienso que mi amado Pepe podrá con sus talentos, con su genio, conquistar esa gloria que yo adoro, y dejar un nombre a los siglos venideros! No pasar la vida como el resto de los hombres vegetando sobre la superficie de la tierra y después perecer sin que quede ni el recuerdo de su existencia. El deseo de la inmortalidad es la ambición de las almas nobles. [...] Dicen que las mujeres no comprenden el honor y que solo piensan en la vida de aquél que ellas aman... Mi alma, mi vida, está ligada con la de mi Pepe, sin él no solamente no habría felicidad en el mundo para mí sino que ni un momento lo pasaría contento. [...] (488)

Al ligarse a Samper, Acosta ha alcanzado el límite de su concepción de la identidad femenina: a lo sumo, un trasfondo digno para el sujeto notable que, verdaderamente, sólo puede aspirar a fundirse en una figura masculina.

\section{MuJERES: LO SINGULAR Y LO FAMILIAR}

Para terminar de perfilar la singularidad del diario y la figura de Soledad Acosta conviene proyectar los límites de su imagen de lo femenino sobre el ámbito más próximo. Cabe señalar que el espacio de lo familiar en Acosta se define, con muy pocas excepciones, como un espacio de incomprensión femenina. Sin salir de las páginas del diario, acabo de señalar la importancia de la figura de Thérèse Leroux, la amiga de infancia, como “primera decepción” y, a la vez, anuncio de los rasgos de quien habría de “completar” su personalidad, su prometido José María Samper. Alo largo de esas páginas las imágenes de mujer son abundantes y, en ocasiones, decisivas para la construcción de la identidad de la autora. Entre las mujeres que ocupan un lugar “positivo” se encuentra sin duda su prima homónima, Soledad (otras aparecen por el diario, pero ésta es la más cercana); un papel más desdibujado cumplen las amigas “de casa”, sujetos indiferenciados con quienes va a bailes o cuya casa visita ("las” Orrantia, “las” Briceño), que constituyen finalmente el fondo en el que casi se desdibuja la personalidad individual de Soledad para convertirse en una más de las mocitas de la alta burguesía bogotana del XIX. También más o menos borrosa es la figura de las monjas del convento en que esas mocitas se refugian durante la revolución y que reprimen su escritura diarística. ${ }^{28}$ Debe considerarse, asimismo, la formación en casa de la abuela materna (protestante), un modelo también rechazado, ${ }^{29}$

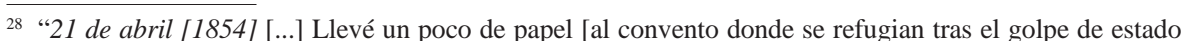
de Melo] para escribir un diario allí pero no me fue posible. Voy a copiar el pedazo que pude escribir. No seguí porque me pareció que a las monjas no les gustaba. [...]” (207).

29 Se lee en el diario: "24 de febrero [1855]. [...] Yo no soy fanática pero soy profundamente religiosa y creo que la que yo he escogido es la mejor para adorar a Dios. Yo no soy Católica sin haber reflexionado mucho sobre esto... Hasta los doce años viví en Bogotá, después fuimos a vivir diez meses con la Madre de mi Mamá que era protestante. Ella trató de convertirme. Mientras estuve allí no leí más sino libros protestantes, no iba sino a iglesias protestantes. Pero, aunque muy niña, escuchaba todo, leía todo, nunca contradecía, pero no me pude convencer. En Francia estudié y comparé los dos cultos, el Católico y el

\footnotetext{
\begin{tabular}{l} 
Revista Iberoamericana, Vol. LXXVI, Núms. 232-233 Julio-Diciembre 2010, 913-937 \\
\hline ISSN 0034-9631 (Impreso)
\end{tabular}
} 
o el hecho -que sin embargo ya no actúa en el diario- de que fruto del matrimonio con Samper nacieran cuatro hijas, dos de las cuales mueren tempranamente, en 1872, a consecuencia de una epidemia, y una tercera decide (a los 40 años, en 1896) entrar a un convento, en contra de la opinión de su madre. Esta hija también morirá antes que Soledad (1910), de modo que, de toda su familia, sólo su hija pequeña, Blanca Leonor, nacida en 1862 parece sobrevivir a Acosta y ocuparse de ella hasta el último momento.

En el momento de la redacción del diario quienes resultan sin duda más importantes son la figuras de la madre y la de la primera esposa de Samper. Aunque bastante desdibujada en el diario y hasta en la vida -no sabemos cuándo muere, por ejemplo-, la figura materna actúa como una presencia que controla e interrumpe la actividad intelectual de Soledad y con la que ésta no se entiende demasiado bien. ${ }^{30}$ Elvira, por su parte, la primera mujer de Samper, fallecida en 1852 (en fecha próxima a la muerte del padre de Acosta), tras haber perdido también, según parece, un hijo, se convertirá en un fantasma que atraviesa el diario de Soledad, fantasma respetado y a la vez temido, frente al que Soledad querrá definitivamente afirmarse, pues duda durante mucho tiempo que su prometido pueda amarla a ella como amó a su "primer amor” y tardará en convencerse de que -en sus palabras- ella pueda ser el verdadero "anteotipo" de Samper.

Se ha dicho que sus estancias en EE.UU. y en Francia permitieron a Soledad conocer otros modelos de mujer distintos de aquellos que podía conocer en Colombia (Alzate 2005). No puede olvidarse, en fin, que la figura de la escritora que firmará como Soledad Acosta de Samper se fragua entre sus dos primeras estancias parisinas, ambas "tuteladas": con sus padres, entre 1847-1850 y con su marido, su madre y sus dos primeras hijas entre 1858-1863. En el periodo que media entre 1850 y 1858, esto es, entre sus 17 y sus 25 años, muere su padre, el diplomático y geógrafo colombiano Joaquín Acosta (1852), conoce al que será su marido, José María Samper (1853), que había enviudado el año anterior; comienza a escribir su diario (1853), que clausurará cuando se case (1855), y nacen dos de sus cuatro hijas (1856 y 1857).

El surgimiento de la escritora Soledad Acosta es, entonces, paralelo a la construcción del espacio familiar propio que se deriva de los datos anteriores. Y en el centro de ese periodo crucial de ocho años, entre 1853 y 1855 comienza la escritura, en forma de diario. Este diario va a cumplir, pues, una función sustitutoria; se convertirá, singularmente, en un "objeto familiar" en el sentido más profundo de la palabra, mediante el cual Soledad

Protestante, y estoy hondamente convencida que el primero es el mejor para mí, porque yo creo que la religión de cada uno se encuentra en el fondo de su corazón y en lo que puede creer. [...]” (503).

30 "18 de noviembre [1853] [...] Perder, ver desaparecer de la tierra a la única persona que me comprendía, a la única persona que sabía lo que era yo porque me parecía en sus sentimientos, en el genio. [...] El pesar había hecho que de una muchacha sin pensamiento, sin ideas, apoyada en mi padre, de repente sintiera que el apoyo se me había ido y que estaba sola. Mi madre estaba ahí, pero ella no me comprende, no toma interés en mi instrucción, en mi espíritu. Su amor hacia mí es grande, pero no me conoce.... [...]” (82-83).

Revista Iberoamericana, Vol. LXXVI, Núms. 232-233 Julio-Diciembre 2010, 913-937 
se construye una especie de alter ego, que llena la ausencia entre la desaparición del padre y la aparición de un nuevo interlocutor, su prometido. En ese diálogo consigo misma, mediado por el diario como objeto, nace la singular escritura de Soledad Acosta.

\section{BiBLIOGRAFÍA}

Acosta de Samper, Soledad. Diario íntimo y otros escritos. Edición y notas de Carolina Alzate. Bogotá: Instituto Distrital de Cultura y Turismo, 2004. XLVII.

Novelas y cuadros de la vida sur-americana. Gante: Imprenta de Eug. Vanderhaeghen; en Biblioteca Virtual Miguel de Cervantes, 1869. <http://www. alcudiavirtual.ua.es/servlet/SirveObras/bvj/35794907878246507754491/index. htm>

Alzate, Carolina. "Configuración de un sujeto autobiográfico femenino en la Bogotá de los 1850”. Coloquio Internacional dedicado a Soledad Acosta, La Habana-Casa de las Américas, 2005. <http://laventana.casa.cult.cu/modules.php?name=News \&file=article\&sid $=2483>$

Aristizábal Peraza, Juanita Cristina. "Reflexiones sobre la escritura en el diario de Soledad Acosta”. Coloquio Internacional dedicado a Soledad Acosta, La HabanaCasa de las Américas, 2005. < http://laventana.casa.cult.cu/modules.php?name=N ews\&file=article\&sid=2476>

Arriaga Flórez, Mercedes. Mi amor, mi juez: alteridad autobiográfica femenina. Barcelona: Anthropos, 2001.

Didier, Béatrice. Le journal intime [1976]. París: PUF, 1991.

Duque, Félix. Historia de la Filosofía Moderna. La era de la crítica. Madrid:Akal, 1998.

Frye, Northrop. El Gran Código. Una lectura mitológica y literaria de la Biblia. Barcelona: Gedisa, 1988.

Gómez de Avellaneda, Gertrudis. Poesías y epistolario de amor y de amistad. Elena Catena, ed. Madrid: Castalia, 1989.

Gorriti, Juana Manuela. "Lo íntimo”. La tierra natal / Lo íntimo. Santiago Sylvester, ed. Buenos Aires: Fondo nacional de las artes, 1995. 123-227.

Hogan, Rebecca. "Engendered Autobiographies: The Diary as a Feminine Form". Prose Studies: Special Issue on Autobiography and Questions of Gender 14/2 (September, 1991): 95-107.

Hostos, Eugenio María de. Obras completas. Edición crítica. Vol. II: Diario (tomo I) (1866-1869). Río Piedras: Universidad de Puerto Rico, 1990.

Kirkpatrick, Susan. Las románticas. Escritoras y subjetividad en España, 1835-1850. Madrid: Cátedra, 1991.

Lastarria, José Victorino. Diario político (1849-1852). Santiago de Chile: Ediciones Andrés Bello, 1968.

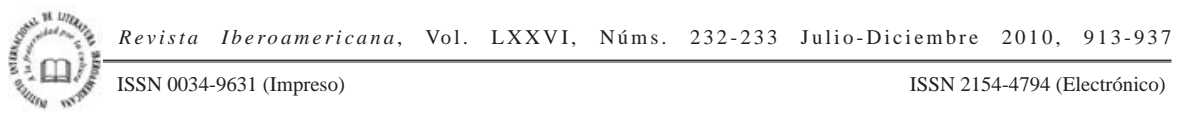


Lejeune, Philippe. Le moi des demoiselles. Enquête sur le journal de jeune fille. París: Seuil, 1993.

Mataix, Remedios. "La escritura (casi) invisible. Narradoras hispanoamericanas del siglo XIX”. Narradoras hispanoamericanas desde la Independencia a nuestros días. Carmen Alemany Bay, ed. Anales de Literatura Española 16 (Alicante, Universidad de Alicante, 2003): 13-82.

Mora, Gabriela. "Hostos intimista: introducción a su Diario". Anales de Literatura Hispanoamericana 2-3 (1973-1974): 311-362.

Mizraje, María Gabriela. "La escritura velada (historia y biografía en Juana Manuela Gorriti)” (1995) <http://lanic.utexas.edu /project/lasa95/gorriti.html>

Oviedo, José Miguel. Historia de la literatura hispanoamericana II. Madrid: Alianza, 1997.

Platón. El banquete / Fedón. Luis Gil, ed. y trad. Barcelona: Planeta, 1982.

Prado, María. "La vida vislumbrada". La vida escrita por mujeres III. La pluma como espada. Del romanticismo al modernismo. Anna Caballé, ed. Barcelona: Lumen, 2004. 15-40.

Ramírez, Liliana. "Huellas de Soledad". Coloquio Internacional dedicado a Soledad Acosta, La Habana-Casa de las Américas, 2005. <http:/laventana.casa.cult.cu/ modules.php?name=News\&file=article\&sid=2492> $($ también en Hipertexto 5 [invierno 2007]: 67-73<http://www.panam.edu/dept/modlang/Hiper5indice.htm>)

Rodríguez-Arenas, Flor María. Bibliografía de la literatura colombiana del siglo XIXtomo I (A-L). Buenos Aires: Stockcero, 2006.

Singer, Irving. La naturaleza del amor 2. Cortesano y romántico. México: Siglo XXI $\left(3^{\mathrm{a}}\right), 1990$.

Shelley, Percy Bysshe. "On Love”. The Works of Percy Bysshe Shelley in Verse and Prose. H. Buxton Forman, ed. Citado por The Percy Bysshe Shelley Resource, 1880. $<$ http://www.wam.umd.edu/ djb/shelley/1880onlove.html>

Ulmer, William Andrew. Shelleyan Eros: The Rhetoric of Romantic Love. Princeton: Princeton UP, 1990.

Vallejo, Catharina. “Los silencios del Diario: autobiografía, ficción y escritura”. Coloquio Internacional dedicado a Soledad Acosta, La Habana-Casa de las Américas, 2005. $<$ http://laventana.casa.cult.cu/modules.php?name=News\&file=article\&sid=2509>

Vidales, Carlos. "Escritoras y periodistas colombianas en el siglo XIX”. La Rana Dorada (s.f.). <http://hem.bredband.net/rivvid/carlos/mujeres.htm>

Revista Iberoamericana, Vol. LXXVI, Núms. 232-233 Julio-Diciembre 2010, 913-937 
